\title{
Study and Proposal for a Hyperfluorinated Brackish Water Treatment System in the Fatick Region, Case of Diouroup (Senegal)
}

\author{
Alioune Ly' ${ }^{1}$ Diadioly Gassama ${ }^{2 *}$, Baba Ngom¹, Famara Seydi Ba², Séni Tamba1 \\ ${ }^{1}$ Laboratory of Sciences and Technologies of Water and Environment, Polytechnic School, Thies, Senegal \\ ${ }^{2}$ Department Physics Chemistry, UFR Science and Technology Iba Der Thiam University, Thies, Senegal \\ Email: *dgassama@univ-thies.sn
}

How to cite this paper: Ly, A., Gassama, D., Ngom, B., Ba, F.S. and Tamba, S. (2021) Study and Proposal for a Hyperfluorinated Brackish Water Treatment System in the Fatick Region, Case of Diouroup (Senegal). American Journal of Analytical Chemistry, 12, 392-407.

https://doi.org/10.4236/ajac.2021.1211024

Received: September 28, 2021

Accepted: November 9, 2021

Published: November 12, 2021

Copyright $\odot 2021$ by author(s) and Scientific Research Publishing Inc. This work is licensed under the Creative Commons Attribution International License (CC BY 4.0).

http://creativecommons.org/licenses/by/4.0/

(c) (i) Open Access

\begin{abstract}
Groundwater is the main resource for human consumption in many countries, especially in developing countries. This groundwater is often brackish and hyperfluorinated, which leads to diseases such as dental and bone fluorosis, etc. The water from the Diouroup water drainage facilities, like those from many other water drainage facilities in the regions of Fatick, Kaolack, Diourbel and the area of Touba, is facing this problem. To solve these problems, several physicochemical and membrane methods have been implemented. In this work we have briefly outlined some of these methods and we have chosen one of them, low pressure reverse osmosis. In addition, this technique is very simple to operate and maintain. Reverse osmosis provides good quality water in a single step, without the need for additional sterilization or remineralization treatments. We then carried out simulations with the Reverse Osmosis System Analysis (ROSA) software. For reasonable operating parameters, we have noticed a low feed pressure of 11.58 bars, a good average flow of raw water of $27.79 \mathrm{~L} / \mathrm{m}^{2} / \mathrm{h}$ and a recovery rate of the first pass of $75.01 \%$. The results obtained also showed a good quality of the permeate which respects the recommendations of the World Health Organization (WHO) on drinking water. The fluorides of $0.59 \mathrm{mg} / \mathrm{L}$ have a recovery rate of $90.8 \%$ while the chlorides of $59.09 \mathrm{mg} / \mathrm{L}$ have a recovery rate of $92.12 \%$ as for the Total Dissolved Solids of $184.90 \mathrm{mg} / \mathrm{L}$ for an abatement of $92 \%$. Finally, the low energy consumption of the process makes it possible to consider it in coupling with an electric supply by photovoltaic solar collectors for isolated sites.
\end{abstract}

\section{Keywords}

Brackish Water, Drinking Water, Fluoride, Reverse Osmosis, Diouroup 


\section{Introduction}

Today, more than one billion people in the world lack access to clean water and half of the population in the developing world suffers from diseases due to water contamination [1]. High quantities of fluorides are often found in groundwater from the captive aquifers of phosphate-producing countries. Fluoride poses public health problems, for example in India, where research with CEFIRES [2] [3] is available, but also in Senegal, China, Russia, the United States, etc. In countries, such as the United States, the Commonwealth of Independent States, North Africa and West Africa, including Senegal, the fluorides attributed to fluorine ores (fluoroapatite) are generally due to the presence of phosphates (hydroxyapatite). Fluoride concentrations in these regions can reach values of 5 to $15 \mathrm{mg} / \mathrm{L}$, whereas the potability standards are $1.5 \mathrm{mg} / \mathrm{L}$ [4]. Water quality monitoring data collected over the past decade in urban drinking water systems call for a re-evaluation of water and health issues in developed countries [5].

The consumption of hyperfluorinated brackish water is the cause of serious poisoning. Consumed at low levels, fluorides are necessary and beneficial for the body such as protection against tooth decay. However, at high concentrations, above $1.5 \mathrm{mg} / \mathrm{L}$, they are toxic and lead to dental and bone fluorescence. This fluoride poisoning in some regions is serious and is a real public health problem [6].

Studies have been conducted to better understand the origin and transport of fluorides in water [7] [8] [9]. In Senegal, this hyperfluorinated water is generally brackish and their salinity can sometimes exceed $2.5 \mathrm{~g} / \mathrm{L}$. The populations of the central zone of Senegal (Fatick, Kaolack, Diourbel) who consume these water are confronted with dental and bone fluorescence. To face the health problems caused by the consumption of these hyperfluorinated brines, a treatment is necessary [10].

The aim of this study is to propose a method of treatment of brackish and fluoridated water in Senegal, more precisely in Diouroup, in the region of Fatick. The chosen method is the reverse osmosis at low pressure.

\section{Materials and Methods}

The region of Fatick was born from the partition of the former region of Sine Saloum in 1984. It is limited to the East by the Kaolack region, to the West by the Atlantic Ocean, to the North by the Diourbel region, to the North-West by the Thiès region, to the South by the Gambia. Figure 1 shows the administrative map of the Fatick region. Figure 2 shows the Diouroup location.

\subsection{Characterization of Fluorides and Chlorides}

Fluorine which is one of the most abundant elements in the earth's crust occurs in the form of fluorite $\left(\mathrm{CaF}_{2}\right)$, biotite $\left((\mathrm{Mg}, \mathrm{Fe})_{2} \mathrm{Al}_{2}(\mathrm{~K}, \mathrm{H})\left(\mathrm{SiO}_{4}\right)_{2}\right)$, cryolite $\left(\mathrm{Na}_{3}\left(\mathrm{AlF}_{6}\right)\right)$ and fluoro-apatite $\left(\mathrm{Ca}_{10} \mathrm{~F}_{2}\left(\mathrm{PO}_{4}\right)_{6}\right)$ [11] [12] [13]. 


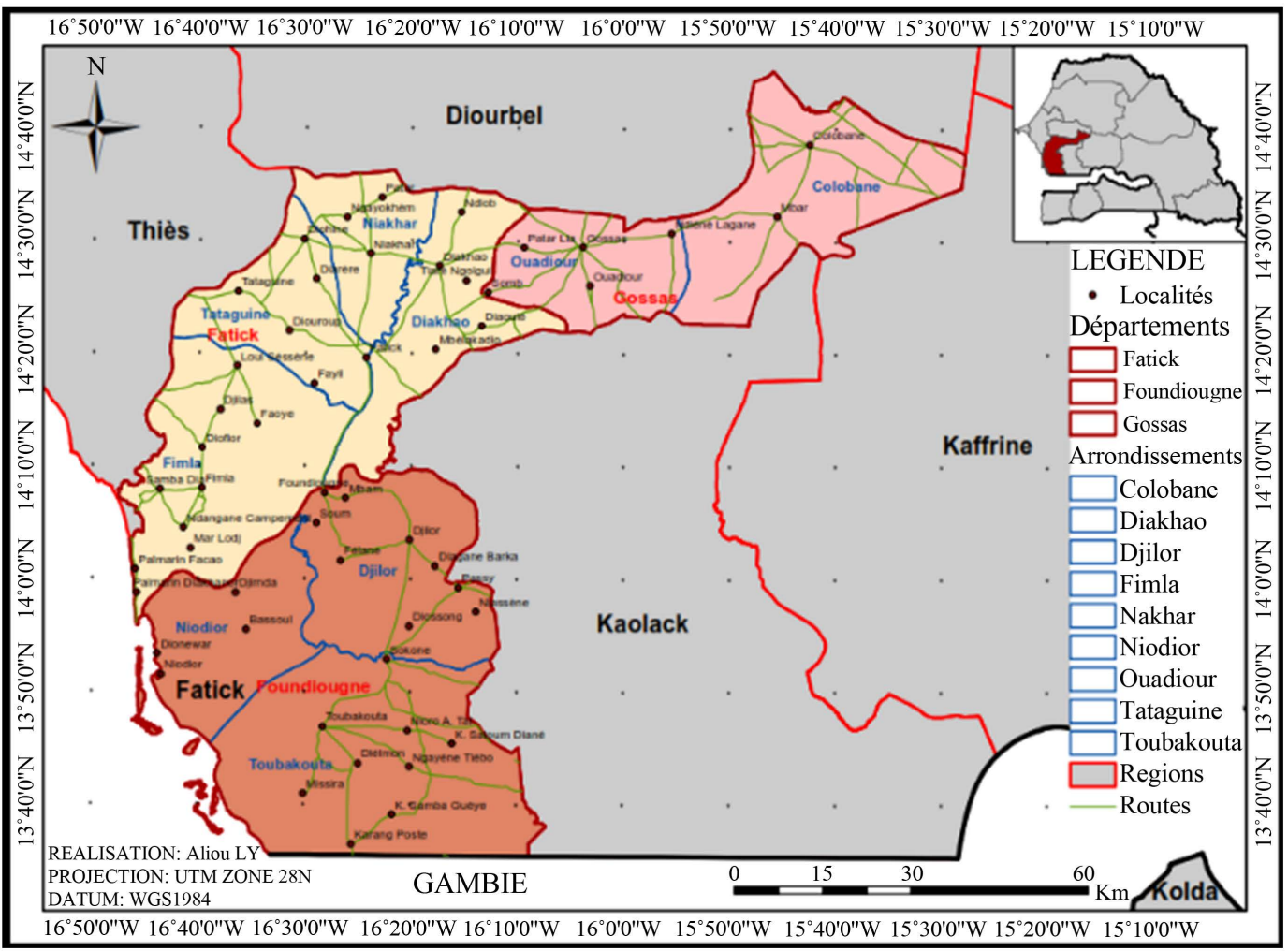

Figure 1. Administrative map of the Fatick region.

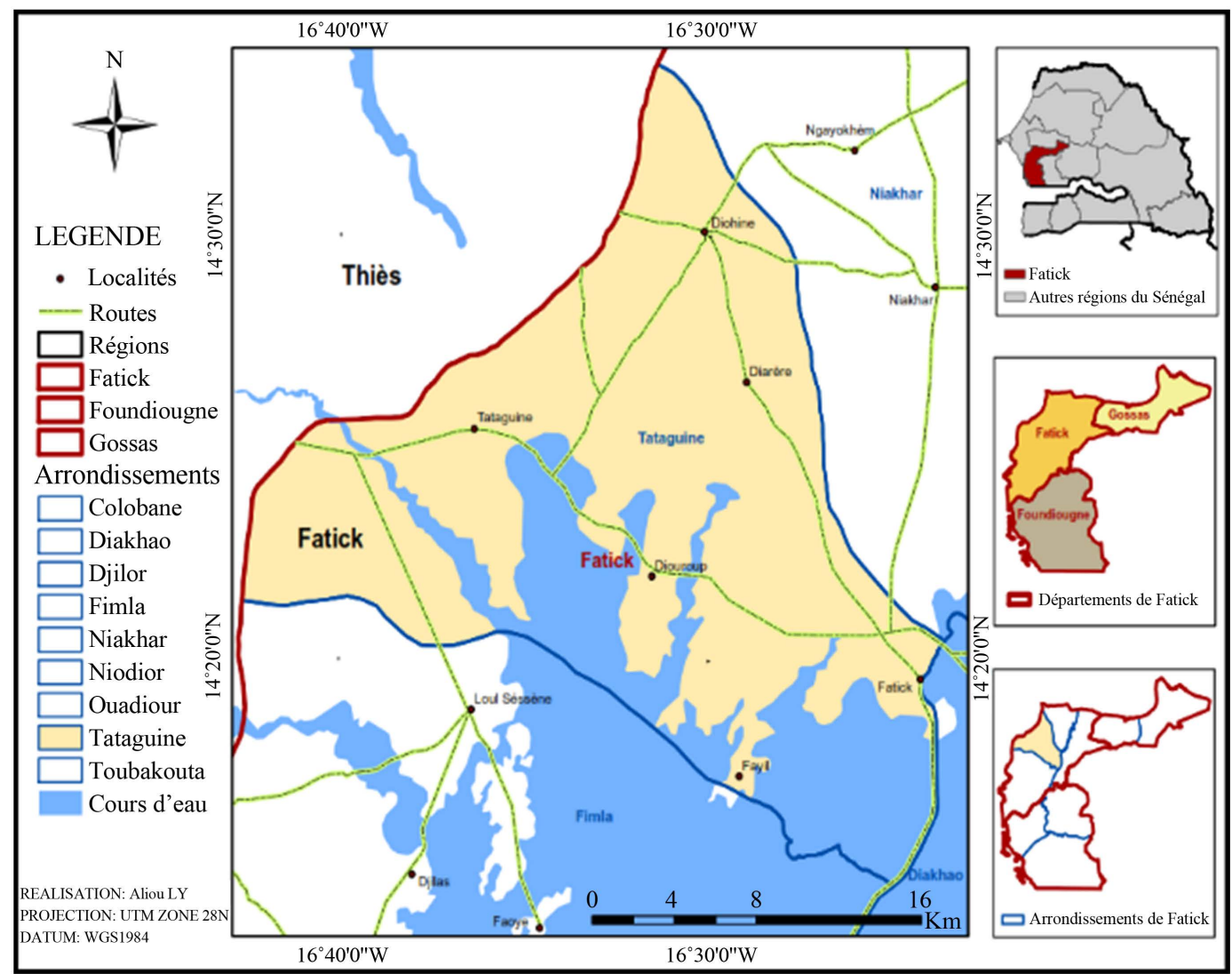

Figure 2. Location map of Diouroup. 
Usually, in surface water, we find very low levels of fluoride ions because these minerals are not very soluble in water. On the other hand, the contact of these rocks with the physicochemical characteristics of certain salts and water tables at high temperatures, for example, leads to the dissolution of these fluoride minerals. The $\mathrm{F}^{-}$ion, which is a very powerful oxidizer and the most electronegative halogen of the elements; this ionic form is the most stable state of fluorine. It is an atom of fluorine which has a layer saturated by the gain of an electron [14]. By gaining an extra electron, the chlorine atom becomes the chloride ion, which is a halide. The ion can also be obtained by the dissociation of hydrogen chloride in water. It can be inorganic (mineral, metallic) or organic (e.g. chloromethane, also called methyl chloride) [14]. Research has identified a wide variety of possible sources of fluoride and chloride, both natural and anthropogenic [14]-[19].

\subsection{Choice of Treatment Process}

There are several processes for the removal of fluorides and chlorides. Among them we can mention the membrane processes of electrodialysis, reverse osmosis and nano filtration and the physicochemical processes that precipitation, adsorption and ion exchange [20]-[26].

Among all the methods, we have chosen reverse osmosis. Reverse osmosis is a system of water purification by permeation through very thin semi-selective membranes that allow only water molecules to pass through. Two solutions of different concentrations are placed on either side of a membrane. The water leaves the less concentrated medium towards the more concentrated medium (this is the phenomenon of osmosis). On the side of the more concentrated compartment, a pressure is applied which is higher than the osmotic pressure of the water. By reversing the phenomenon of osmosis in this way, pure water is transferred from the concentrated medium to the diluted medium [27]. The influencing factors are operating pressure, temperature and permeate flow.

Like any membrane process, reverse osmosis has its advantages and disadvantages [28] [29] [30] [31].

The advantages are the removal of fluoride and chloride ions contained in water, bacteria, viruses of microorganisms and heavy organic compounds that can be carcinogenic. There is no selectivity between salts and very effective, the retention of Chemical Oxygen Demand lasts, as well as salts, metals and nitrates [32]. Based on the advantages, disadvantages and the nature of the pollutants to be removed, i.e. fluorides and chlorides, we have chosen the low pressure reverse osmosis process because of its performance, its hydraulic and qualitative security. Chlorides and fluorides have a comparable ionic radius of 100 and $50 \mathrm{pm}$ respectively. The membranes that remove fluorides also remove chlorides. After proposing the reverse osmosis process, it is important to choose the types of membranes involved in order to optimize water productivity and energy costs [33].

In addition to these advantages, reverse osmosis makes it possible to meet the 
requirements of the treatment of the main quality problems of raw water, obtaining a process that allows the distribution of water in accordance with the recommendations of the $\mathrm{WHO}$ and the distribution of a pleasant drink. Reverse osmosis membranes are also capable of removing chlorides and fluorides contained in water up to a respective percentage of $89.7 \%$ for chlorides and $94.4 \%$ for fluorides [34].

Reverse osmosis was one of the membrane technologies chosen for the treatment of groundwater containing fluoride concentrations up to more than 30 $\mathrm{mg} / \mathrm{L}$ [35].

According to the studies of Walha et al. [36], the treatment of fluoride with reverse osmosis on water taken from the south of Tunisia containing a salinity of 3 to $6 \mathrm{~g} / \mathrm{L}$ has allowed to obtain a retention rate of $95 \%$ with an elimination of inorganic elements which are present in the raw water. Other studies have also shown the effectiveness of reverse osmosis on the removal of fluoride and chloride with an elimination rate of about $60 \%$ for water containing a fluoride concentration of $1.7 \mathrm{mg} / \mathrm{L}$ [37] [38].

\subsection{Sampling}

Sampling was carried out at the test point at the water tower. The analysis of the physicochemical parameters temperature, $\mathrm{pH}$, conductivity and total dissolved solids was carried out in situ with a portable multi-parameter Multi 340i field device. Afterwards we took the information in relation to the hourly and daily flow rates of the water drainage facility. The sample is stored in vials containing conservation reagents, kept cool in a cooler and sent to the laboratory for further physico-chemical analysis.

We used a Dionex DX-120 ion chromatograph to determine the chemical parameters of major ions $\left(\mathrm{Ca}^{2+}, \mathrm{Mg}^{2+}, \mathrm{Na}^{+}, \mathrm{K}^{+}, \mathrm{Cl}^{-}, \mathrm{F}^{-}, \mathrm{SO}_{4}^{2-}, \mathrm{NO}_{3}^{-}\right)$.

The study was carried out on a sample of water from the Diouroup commune water drainage facilities.

\subsection{Treatment Simulation}

This simulation is carried out with the physico-chemical characteristics of the water from the Diouroup well on a reverse osmosis membrane filtration system, with: a 5 micron pre-filtration, an integrated membrane washing system, a programmable controller and a cycle indication by Light-Emitting Diodes (LED) lights. The dimensions are: $1.52 \mathrm{~m} \mathrm{~W} \times 0.9 \mathrm{~m} \mathrm{D} \times 1.7 \mathrm{~m} \mathrm{H}$ the control module and $0.53 \mathrm{~m} \mathrm{~W} \times 0.33 \mathrm{~m} \mathrm{D} \times 1.7 \mathrm{~m} \mathrm{H}$ per membrane.

Model: MiniMéga-4Number of membranes: 4; Type of membranes: Xtremely Low Energy (XLE)-440 from Filmtec. The software used is Reverse Osmosis System Analysis (ROSA) and Integral Configuration Method (ICM) configuration DB 35240041.

The reverse osmosis system analysis for FILMTEC ${ }^{\mathrm{T}}$ ROSA v6.1 membranes is done on the Diouroup project of $100 \mathrm{~m}^{3} / \mathrm{d}$ flow rate. 


\section{Results and Discussion}

The water from the Diouroup commune water drainage facilities is underground water with an hourly flow rate of $20 \mathrm{~m}^{3} / \mathrm{h}$, during the dry season, the daily flow rate is $40 \mathrm{~m}^{3} / \mathrm{d}$ and during the winter period, the daily flow rate is $50 \mathrm{~m}^{3} / \mathrm{d}$.

\subsection{Raw Water and Permeate Analysis}

The analysis reveals that this water is brackish and hyperfluorinated. The data of physicochemical parameters on water are presented in Table 1.

A comparison of the results of the raw water and permeate analyses obtained during piloting allows us to observe that the desired water quality objectives were achieved. These objectives involved the following parameters: chlorides, fluorides, conductivity, total hardness, manganese and total dissolved solids. It is observed that each of the critical raw water parameters achieved values below the WHO standards for drinking water quality [39].

\subsection{Treatment Simulation}

In this simulation, we introduced into the simulator the raw water characteristics obtained from the sample analysis. The operating parameters used during this operation are presented in Table 2.

The operating parameters for each of the components of the low pressure reverse osmosis module during the simulation are presented in Table 3 below.

We present in Table 4 the scaling of the calculations of the different indices obtained with the simulation.

\subsection{Equation}

However, to balance, $3.50 \mathrm{mg} / \mathrm{L} \mathrm{Na}$ is added to feed.

In this same Table 5, we also have the ion concentrations of the raw water. , permeate and percentages and comparison of results to standards and limits.

Table 1. Physicochemical characteristics of raw water.

\begin{tabular}{|c|c|c|c|}
\hline \multicolumn{3}{|c|}{ Physico-chemical parameters } & Contents \\
\hline \multicolumn{3}{|c|}{$\mathrm{pH}$} & 8.16 \\
\hline \multicolumn{3}{|c|}{ Temperature ${ }^{\circ} \mathrm{C}$} & 33.1 \\
\hline \multicolumn{3}{|c|}{ Conductivity $(\mu \mathrm{S} / \mathrm{cm})$} & 3500 \\
\hline \multicolumn{3}{|c|}{ Total dissolved solids: TDS (mg/L) } & 2302.46 \\
\hline Cations & Concentrations $(\mathrm{mg} / \mathrm{L})$ & Anions & Concentrations $(\mathrm{mg} / \mathrm{L})$ \\
\hline $\mathrm{Ca}^{2+}$ & 8.16 & $\mathrm{Cl}^{-}$ & 750.33 \\
\hline $\mathrm{Mg}^{2+}$ & 3.75 & $\mathrm{SO}_{4}^{2-}$ & 123.80 \\
\hline $\mathrm{Na}^{+}$ & 759.19 & $\mathrm{HCO}_{3}^{-}$ & 610.00 \\
\hline \multirow[t]{2}{*}{$\mathrm{K}^{+}$} & 24.79 & $\mathrm{NO}_{3}^{-}$ & 5.16 \\
\hline & & $\mathrm{F}^{-}$ & 6.41 \\
\hline
\end{tabular}


Table 2. Membrane treatment simulation parameters.

\begin{tabular}{|c|c|c|c|}
\hline Parameters & Values & Parameters & Values \\
\hline Feed flow in step 1 & $16.96 \mathrm{~m}^{3} / \mathrm{h}$ & $\begin{array}{c}\text { Flow rate Permeate } \\
\text { pass } 1\left(1^{\text {st }} \text { pass }\right)\end{array}$ & $4.54 \mathrm{~m}^{3} / \mathrm{h}$ \\
\hline Raw water flow in the network & $6.06 \mathrm{~m}^{3} / \mathrm{h}$ & Recovery rate passes 1 & $75.01 \%$ \\
\hline Supply pressure & 11.58 bar & Supply temperature & $25.0^{\circ} \mathrm{C}$ \\
\hline Fouling factor & 0.85 & TDS Power supply & $2305.97 \mathrm{mg} / \mathrm{L}$ \\
\hline Chemical doses $\left(100 \% \mathrm{H}_{2} \mathrm{SO}_{4}\right)$ & $0.00 \mathrm{mg} / \mathrm{L}$ & Number of elements & 4 \\
\hline Total active area & $163.50 \mathrm{~m}^{2}$ & $\begin{array}{c}\text { Average flow } \\
\text { pass } 1\left(1^{\text {st }} \text { pass }\right)\end{array}$ & $27.79 \mathrm{~L} / \mathrm{m}^{2} / \mathrm{h}$ \\
\hline $\begin{array}{c}\text { Water Classification: } \\
\text { Water drainage facilities } \\
\text { Water SDI }\end{array}$ & $<3$ & & \\
\hline Parameters & Values & Parameters & Values \\
\hline Step & 1 & Element & XLE-440 \\
\hline Pass number & 1 & Element number & 4 \\
\hline Feed flow $\left(\mathrm{m}^{3} / \mathrm{h}\right)$ & 16.96 & Supply pressure (bar) & 11.24 \\
\hline Recirculation flow $\left(\mathrm{m}^{3} / \mathrm{h}\right)$ & 10.90 & $\begin{array}{c}\text { Flow rate } \\
\text { Concentrate }\left(\mathrm{m}^{3} / \mathrm{h}\right)\end{array}$ & 12.42 \\
\hline Concentrate pressure (bar) & 9.10 & Permeate flow $\left(\mathrm{m}^{3} / \mathrm{h}\right)$ & 4.54 \\
\hline Average filtration flow $\left(\mathrm{L} / \mathrm{m}^{2} / \mathrm{h}\right)$ & 27.79 & Permeate pressure (bar) & 0.00 \\
\hline Boost pressure & 0.00 & TDS Permeate $(\mathrm{mg} / \mathrm{L})$ & 184.90 \\
\hline
\end{tabular}

Table 3. Operating parameters for each module element during the simulation.

\begin{tabular}{|c|c|c|c|c|c|c|c|}
\hline & Elements & Recovery & $\begin{array}{c}\text { Permeate } \\
\text { flow rate } \\
\left(\mathrm{m}^{3} / \mathrm{h}\right)\end{array}$ & $\begin{array}{c}\text { TDS } \\
\text { Permeate } \\
(\mathrm{mg} / \mathrm{L})\end{array}$ & $\begin{array}{c}\text { Feed } \\
\text { flow } \\
\left(\mathrm{m}^{3} / \mathrm{h}\right)\end{array}$ & $\begin{array}{c}\text { TDS } \\
\text { feeder } \\
(\mathrm{mg} / \mathrm{L})\end{array}$ & $\begin{array}{c}\text { Supply } \\
\text { pressure } \\
\text { (bar) }\end{array}$ \\
\hline \multirow[t]{4}{*}{ Step 1} & 1 & 0.09 & 1.45 & 133.72 & 16.96 & 6408.31 & 11.24 \\
\hline & 2 & 0.08 & 1.23 & 167.54 & 15.51 & 6991.72 & 10.61 \\
\hline & 3 & 0.07 & 1.03 & 210.72 & 14.29 & 7575.60 & 10.05 \\
\hline & 4 & 0.06 & 0.85 & 266.08 & 13.26 & 8143.79 & 9.56 \\
\hline
\end{tabular}

Table 4. Scaling of calculations of some indices obtained during the simulation.

\begin{tabular}{cccc}
\hline Size & Raw water & Adjusted flow & Concentrate \\
\hline $\mathrm{pH}$ & 8.16 & 8.16 & 8.12 \\
Langelier Saturation Index & 0.22 & 0.22 & 1.30 \\
Sniff \& Davis Stability Index & 0.37 & 0.37 & 0.95 \\
Ionic strength (molar) & 0.04 & 0.04 & 0.14 \\
\hline
\end{tabular}




\section{Continued}

\begin{tabular}{cccc}
\hline TDS $(\mathrm{mg} / \mathrm{L})$ & 2302.46 & 2305.97 & 8680.12 \\
$\mathrm{HCO}_{3}^{-}$ & 610.00 & 610.00 & 2229.40 \\
$\mathrm{CO}_{2}^{-}$ & 4.64 & 4.64 & 14.33 \\
$\mathrm{CO}_{3}^{2-}$ & 10.85 & 10.85 & 74.72 \\
(\% saturation) $\mathrm{CaSO}_{4}$ & 0.16 & 0.16 & 1.05 \\
(\% saturation) $\mathrm{CaF}_{2}$ & 44.57 & 44.57 & 2448.69 \\
(\% saturation) $\mathrm{Mg}(\mathrm{OH})_{2}$ & 0.00 & 0.00 & 0.01
\end{tabular}

Table 5. Flow of passage of ions, permeate, reduction percentages and standards and limits.

\begin{tabular}{|c|c|c|c|c|c|c|c|}
\hline Symbole & $\begin{array}{c}\text { Flow } \\
\text { Initial } \\
(\mathrm{mg} / \mathrm{L})\end{array}$ & $\begin{array}{c}\text { Flow } \\
\text { Recycling } \\
(\mathrm{mg} / \mathrm{L})\end{array}$ & $\begin{array}{c}\text { Flow } \\
\text { Concentrate } \\
(\mathrm{mg} / \mathrm{L})\end{array}$ & $\begin{array}{c}\text { Final } \\
\text { Concentration } \\
(\mathrm{mg} / \mathrm{L})\end{array}$ & $\begin{array}{c}\text { Recovery } \\
(\%)\end{array}$ & $\begin{array}{l}\text { Permeate } \\
(\mathrm{mg} / \mathrm{L})\end{array}$ & $\begin{array}{l}\text { Norms } \\
\text { and } \\
\text { Limits }\end{array}$ \\
\hline $\mathrm{K}^{+}$ & 24.79 & 66.29 & 89.26 & 3.54 & 85.72 & 3.54 & 12 \\
\hline $\mathrm{Na}^{+}$ & 759.19 & 2128.01 & 2884.79 & 60.11 & 92.08 & 60.11 & 200 \\
\hline $\mathrm{Mg}^{2+}$ & 3.75 & 10.79 & 14.70 & 0.11 & 97.07 & 0.11 & 30 \\
\hline $\mathrm{Ca}^{2+}$ & 8.16 & 23.49 & 32.00 & 0.23 & 97.18 & 0.23 & 200 \\
\hline $\mathrm{CO}_{3}^{2-}$ & 10.85 & 50.61 & 74.72 & 0.02 & 99.81 & - & - \\
\hline $\mathrm{HCO}_{3}^{-}$ & 610.00 & 1654.55 & 2229.40 & 52.82 & 91.34 & 52.82 & 250 \\
\hline $\mathrm{NO}_{3}^{-}$ & 5.16 & 10.27 & 13.07 & 2.64 & 48.84 & 2.64 & 50 \\
\hline $\mathrm{Cl}^{-}$ & 750.33 & 2094.21 & 2839.00 & 59.09 & 92.12 & 59.09 & 250 \\
\hline $\mathrm{F}^{-}$ & 6.41 & 17.72 & 23.99 & 0.59 & 90.08 & 0.59 & 1.5 \\
\hline $\mathrm{SO}_{4}^{2-}$ & 123.80 & 352.34 & 479.18 & 5.74 & 95.36 & 52.82 & 250 \\
\hline $\mathrm{CO}_{2}$ & 4.64 & 10.21 & 14.33 & 10.07 & 53.92 & - & - \\
\hline TDS & 2302.46 & 6408.31 & 8680.12 & 184.90 & 91.97 & 184.90 & 1000 \\
\hline $\mathrm{pH}$ & 8.16 & 8.17 & 8.12 & 6.88 & 15.69 & 6.88 & 6.5 à 8.5 \\
\hline $\begin{array}{l}\text { Conductivity } \\
(\mu \mathrm{S} / \mathrm{cm})\end{array}$ & & & & & & 282 & 200 et 1100 \\
\hline
\end{tabular}

The fluxes of each ion at the raw water, recycle and concentrate levels during the membrane filtration simulation are summarized in Table 5. The flow of the ions through the raw water supply, the recycling and the concentrate during the simulation are grouped together in Table 5. In this same Table 5, we also have the ion concentrations of the raw water, permeate and percentages and comparison of results to standards and limits.

The results of the physico-chemical characteristics of the water obtained after the simulation are presented in Table 5. Compared to the standards, these results allow us to deduce that this treatment is effective. The results of the chemical analyses in Table 5 of the permeate obtained under the conditions indicated 
show that low pressure reverse osmosis is effective. Indeed, it allows to reduce the concentration of inorganic elements that are present in the raw water to meet the WHO standards and this without being obliged to resort to remineralization [40]. Below, we compare the individual concentrations of each ion $(\mathrm{mg} / \mathrm{L})$ in the raw and permeate water to the standards and limits.

The solubility warnings are as follows: Langelier saturation index $>0$, Sniff \& Davis stability index (SDI) $>0$ and $\mathrm{CaF}_{2}$ (\% saturation) $>100 \%$.

In the histogram (Figure 3), we represent the flux of each ion in the raw water, in the recirculated water and in the concentrate.

In this study, we adopted the experimental conditions so that the feed pressure was 11.58 bar for a raw water flow rate of $6.06 \mathrm{~m}^{3} / \mathrm{h}$, corresponding to a permeate flow rate of about $27.79 \mathrm{~L} / \mathrm{m}^{2} / \mathrm{h}$. We thus have a permeate flow of 4.54 $\mathrm{m}^{3} / \mathrm{h}\left(108.96 \mathrm{~m}^{3} / \mathrm{d}\right)$, a recovery rate of $75.01 \%$ and a fluoride reduction rate of $90.08 \%$.

Below, we compare the individual concentrations of each ion $(\mathrm{mg} / \mathrm{L})$ in the raw and permeate water to the standards and limits (Figure 4).

The concentrations of the various ions $(\mathrm{mg} / \mathrm{L})$ in the raw water and permeate, as well as the percentage removal of each ion individually, are shown in the histogram in Figure 5.

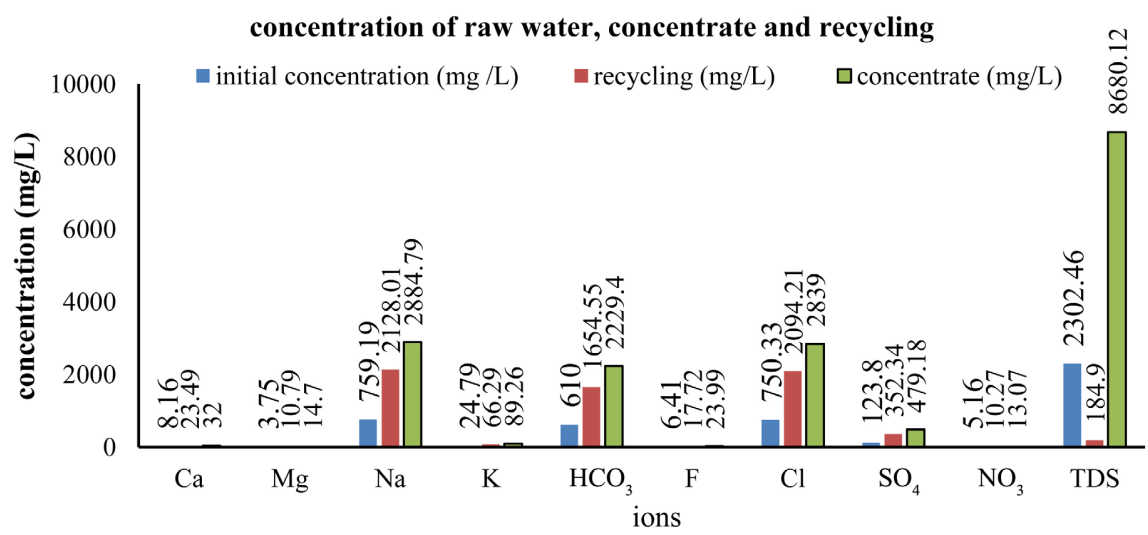

Figure 3. Graph of concentrations, initials, recycling and concentrate.

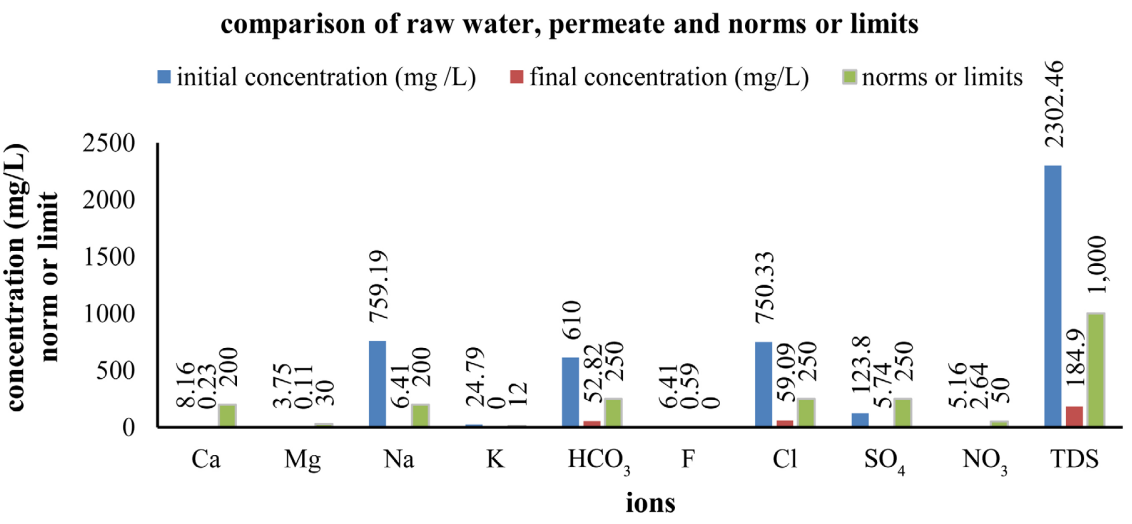

Figure 4. Graph comparing raw water, permeate and standards or limits. 


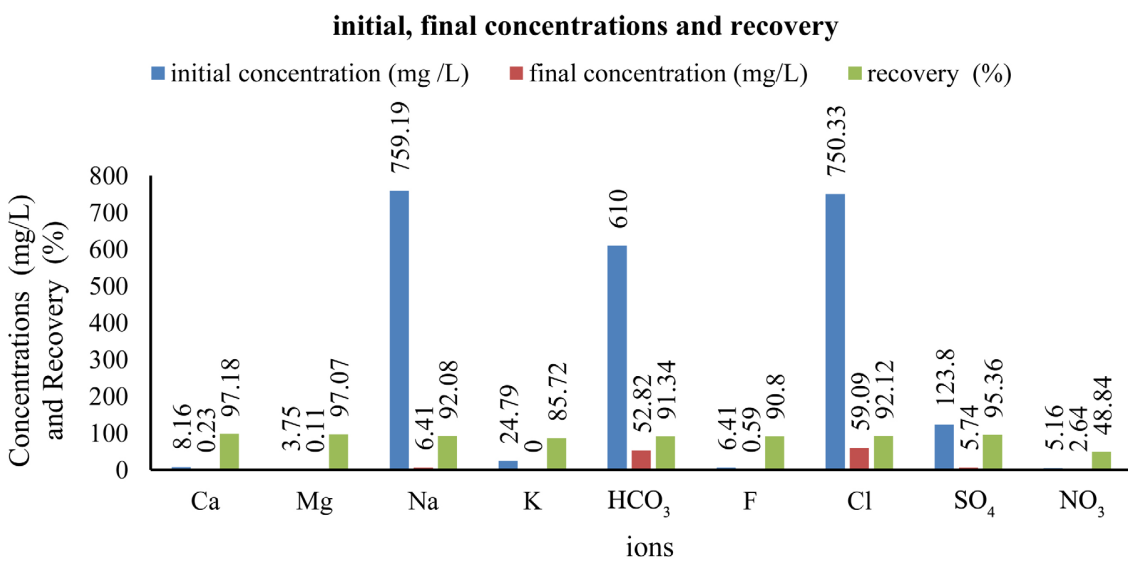

Figure 5. Overlay graph.

From the reading of this recovery histogram, we can conclude that this treatment technic is effective.

The results of the SDI (Silt density index) analysis performed on raw water samples revealed that the raw water contained an SDI smaller than 3, which means a very low clogging potential for the membrane. This result allows us to conclude that specific pre-treatments such as a sand filter or a multilayer filter are not necessary. Only an antiscalant dosage and the use of a 5 micron prefilter, upstream of the low pressure Reverse Osmosis (RO) system, are required.

With a recovery rate of $75 \%$, the purified water flows are relatively stable, provided that the dosage of the antiscalant added to the raw water is well controlled. The quality of the treated water obtained by low pressure reverse osmosis largely meets the maximum standards allowed for drinking water. No pre-treatment other than an antiscalant injection and a 5 micron pre-filtration is required. The frequency of membrane washing can be once every 2 months of operation due to the stability of the flow rate at 12.41 bars.

This simulation allowed us to establish the necessary data for the configuration and proposal of a hyperfluorinated brackish water treatment system by reverse osmosis at low pressure configured with 4 membranes to treat the water of the Diouroup area's well.

\subsection{Description of the Selected System}

We will first describe the different parts that make up the processing system and briefly explain their functions and operation.

The technology is for low pressure reverse osmosis treatment of brackish groundwater for the removal of fluoride, chloride, sodium, hardness, calcium, and dissolved solids. It is a treatment chain involving only a dosage of antiscalants to reduce mineral deposition on the membrane followed by pressure membrane filtration through spiral modules.

In the Mini-Méga treatment system, an antiscalant solution is injected into the raw water. The pre-treated raw water passes through a 5-micron cartridge prefilter with an integrated automatic washing system and then over tangential re- 
verse osmosis membranes. A concentrate recirculation loop is provided to increase the flow velocity to the membranes and thus reduce their clogging. The entire flow of water to be treated will be filtered through the membranes (permeate) and the concentrate will be conveyed to the discharge. Chemical washing is required when the corrected transmembrane pressure has increased by $15 \%$.

The flow diagram is shown in Figure 6.

The system is essentially composed of an anti-scaling pre-treatment, a filter and an automatic washing system incorporated, a low pressure reverse osmosis membrane system and a treatment station for possible $\mathrm{pH}$ corrections.

The selected system consists of pre-treatment, treatment and membrane characteristics.

Pre-treatment is primarily used against scaling to protect the membranes from rapid clogging in order to extend the life of the membranes. The antiscalant dosing is done by a dosing pump system with accessories from Prominent or equivalent for antiscalant injection including a 130 litre dilution tank $(457 \mathrm{~mm}$ $\mathrm{D} \times 813 \mathrm{~mm} \mathrm{H}$ ), operating in duplex mode for a concentration of $2.4 \mathrm{mg} / \mathrm{L}$.

The different elements that make up the actual processing part and their characteristics are listed and described below.

Mini-Mega membrane system:

- A reverse osmosis membrane filtration system,

- 5 micron pre-filtration,

- Integrated membrane washing system,

- Programmable logic controller,

- Cycle indication by LED lights.

Dimensions:

- The control module $1.52 \mathrm{~m} \mathrm{~W} \times 0.9 \mathrm{~m} \mathrm{D} \times 1.7 \mathrm{~m} \mathrm{H}$,

- 4 membranes of $0.53 \mathrm{~m} \mathrm{~W} \times 0.33 \mathrm{~m} \mathrm{D} \times 1.7 \mathrm{~m} \mathrm{H}$ each,

- Model: MiniMéga-4,

- Number of membranes: 4.

Membrane type: XLE-440 from Film tec

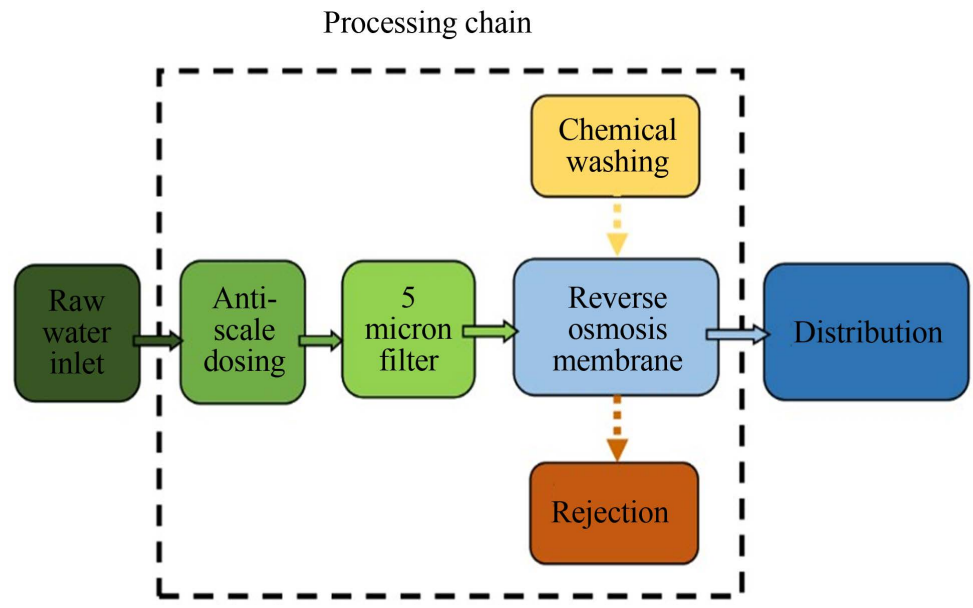

Figure 6. Flow diagram. 
Instrumentation:

- A conductivity meter from Endress and,

- Hauser or equivalent to check the water quality.

The characteristics of the membrane are as follows:

- Type of membrane used: XLE-440 from Dow-Filmtec,

- Filtration mode: pressure gradient with tangential flow,

- Membrane characteristics: spiral modules,

- Composition: Polyamide composite membranes,

- Diameter of a membrane module: $53 \mathrm{~cm}$,

- Permeate tube diameter: $3.81 \mathrm{~cm}$,

- Length of a module: $170 \mathrm{~cm}$,

- Total filtration area: $37 \mathrm{~m}^{2}$,

- Average cut-off: 200 Daltons.

We have presented the flow diagram of the selected proposed system, with the different elements that compose it in Figure 7.

The literature published by the various $\mathrm{RO}$ manufacturers indicates a wide range of fluoride removal from $40 \%$ to $90 \%$. Although $\mathrm{RO}$ is not generally used on low TDS water and is not specifically used for fluoride removal, the process is an effective method. Membrane processes are a very efficient technique and no chemicals are required. It works in a wide $\mathrm{pH}$ range and interference by other ions is negligible [41].

In recent years, the reverse osmosis membrane process has emerged as a preferred alternative for providing potable water without the problems associated with other conventional methods. Progressive technical improvements in membrane design and materials have made the water treatment process economically competitive and highly reliable. In addition, the capital and operating costs of the reverse osmosis plant continue to decrease as the capacity of the plant increases. Thus, with better management, this new technology for drinking water

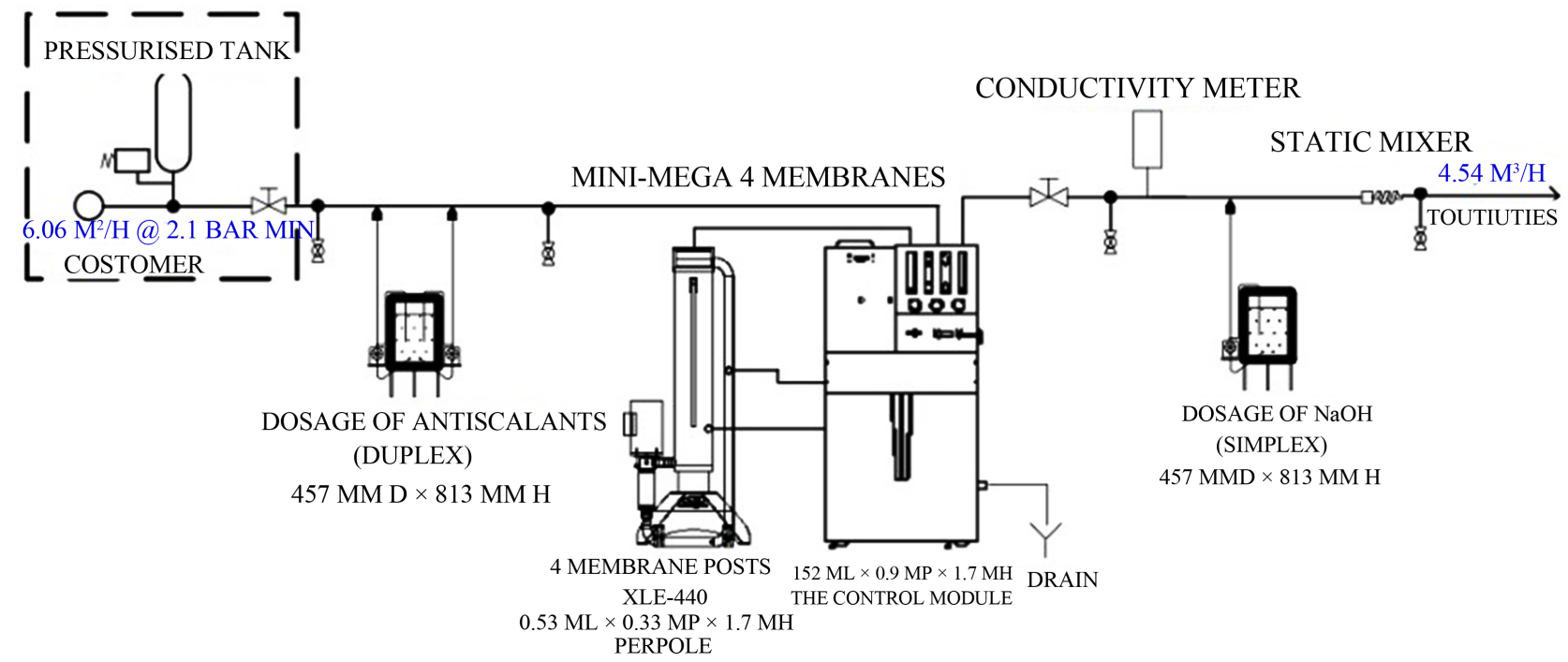

Figure 7. Flow diagram of the proposed system. 
production could be the best option. In addition, membrane processes have real advantages over other treatment methods [42].

\section{Conclusions}

In Senegal, hyperfluorinated brackish groundwater is generally the cause of several diseases. Hydrochemical and geotechnical studies on the sedimentary basin of Senegal have shown that the waters of the Maastrichtian aquifer contain significant amounts of fluoride and chloride. However, these waters constitute an important source of supply for the populations of the groundnut basin. This therefore results in the need to treat this drinking water.

The simulation methodology with ROSA software and Film Tec XLE-440 membranes adopted in this study allowed us to obtain satisfactory results. These results can be summarized mainly into two categories. Regarding reasonable operating parameters, we observed a low supply pressure of 11.58 bars for an average raw water flow rate of $27.79 \mathrm{~L} / \mathrm{m}^{2} / \mathrm{h}$ and the recovery rate of the first pass is by $75.01 \%$. Fluorides with a content of $0.59 \mathrm{mg} / \mathrm{L}$ have a recovery rate of $90.8 \%$. As for chlorides with a concentration of $59.09 \mathrm{mg} / \mathrm{L}$, they have a recovery rate of $92.12 \%$. There was a reduction of $92 \%$ for total dissolved solids of $184.90 \mathrm{mg} / \mathrm{L}$.

The proposed system provides good quality water that meets WHO standards for drinking water. Unlike conventional chemical treatments which require expensive chemical additions, major civil engineering work and qualified maintenance, low pressure reverse osmosis makes it possible to obtain recognized quality water in a single step, at low energy cost and with a low level of maintenance. This technique also avoids the need for additional decontamination or remineralization treatments. The relatively low energy consumption makes it possible to envisage mobile units, coupled with photovoltaic or wind power supplies, but they would remain limited to daily productions of 10 to $20 \mathrm{~m}^{3}$.

\section{Conflicts of Interest}

The authors declare no conflicts of interest regarding the publication of this paper.

\section{References}

[1] Faye, C. (2017) Water Pollution Challenges, a Threat to Public Health: Strengths and Weaknesses of Water Laws and Policies in Senegal. LARHYSS Journal, 32, $107-$ 126.

[2] Missaoui, K., Bouguerra, W., Hannachi, C., Gannouni, N. and Hamrouni, B. (2017) Defluoridation of South Tunisian Brackish Water by Alum Coagulation/Flocculation: A Preliminary Work. Journal of Advances in Chemistry, 5, 727-740. \}https://doi.org/10.24297/jac.v5i3.6592

[3] Devi, P.S., Srinivasulu, S. and Raju, K.K. (2001) Hydrogeomorphological and Groundwater Prospects of the Pageru River Basin by Using Remote Sensing Data. Environmental Geology, 40, 1088-1094. https://doi.org/10.1007/s002540100295

[4] Pontié, M., Rumeau, M., Ndiaye, M. and Diop, C.M. (1996) Sur le problème de la 
fluorose au Sénégal: Bilan des connaissances et présentation d'une nouvelle. Cahiers Santé, 6, 27-36.

[5] Makris, K.C. and Andra, S.S. (2014) Limited Representation of Drinking-Water Contaminants in Pregnancy-Birth Cohorts. Science of the Total Environment, 468-469, 165-175. https://doi.org/10.1016/j.scitotenv.2013.08.012

[6] Diawara, C.K. (2004) Contribution à l'étude de la rétention du fluor et de métaux lourds en solution par des procédés membranaires de nanofiltration et d'ultrafiltration. Application à des eaux de boisson de France et du Sénégal et à des solutions de métaux lourds. Université Cheikh Anta Diop de Dakar, Faculté des Science et Technique, Dakar.

[7] Travi, Y. (1993) Hydrogéologie et hydrochimie des aquifères du Sénégal. Hydrogéochimie du fluor dans les eaux souterraines. Université Louis Pasteur, Institut de géologie, Strasbourg.

[8] Alarcon-Herrera, M.T., MartIn-Dominguez, I.R., Trejo-Vázquez, R. and RodriguezDozal, S. (2001) Well Water Fluoride, Dental Fluorosis, and Bone Fractures in the Guadiana Valley of Mexico. Fluoride, 34, 139-149.

[9] Kazi, T.G., Arain, M.B., Jamali, M.K., Jalbani, N., Afridi, H.I., Sarfraz, R.A., et al. (2009) Assessment of Water Quality of Polluted Lake Using Multivariate Statistical Techniques: A Case Study. Ecotoxicology and Environmental Safety, 72, 301-309. https://doi.org/10.1016/j.ecoenv.2008.02.024

[10] Raoul, T.A., Toury, J., Perellon, J., Raba, A., Luven, P. and Giorgi, R. (1957) Premières études sur un foyer de fluorose humaine au Sénégal. Bulletin Media AOF, 2 , 359-371.

[11] Chermette, A., et al. (1996) Nouvelles archives du Muséum d'histoire naturelle de Lyon. Musée Guimet d'histoire naturelle, Lyon.

[12] Diop, S.N., Diawara, C.K., Diasse-Sarr, A., Masse, A., Jaouen, P. and Pontie, M. (2008) Focusing on Excess of Fluoride Removal Process from Drinking Water: Nanofiltration. Journal of Science and Technology, 7, 25-31.

[13] Pontié, M., et al. (2006) Le problème de la fluorose au Sénégal: Bilan des connaissaances et présenation d'une nouvelle méthode de défluoruration des eaux de boisson. Fluor et Envirennement, 301-302, 2-8.

[14] Ndiaye, N.S. (2018) Contribution à l'amélioration de la qualité de l'eau distribuée dans la ville de Fatick (Fatick, Sénégal): Construction d'une station de traitement de fluorure et de chlorure. Institut International d'Ingénierie de l'Eau et de l'Environnement (2iE), Ouagadougou.

[15] Abdelgawad, A.M., Watanabe, K., Takeuchi, S. and Mizuno, T. (2009) The Origin of Fluoride-Rich Groundwater in Mizunami Area, Japan-Mineralogy and Geochemistry Implications. Engineering Geology, 108, 76-85.

https://doi.org/10.1016/j.enggeo.2009.06.016

[16] Viero, A.P., Roisenberg, C., Roisenberg, A. and Vigo, A. (2009) The Origin of Fluoride in the Granitic Aquifer of Porto Alegre, Southern Brazil. Environmental Geology, 56, 1707-1719. https://doi.org/10.1007/s00254-008-1273-5

[17] Nasr, A.B., Charcosset, C., Amar, R.B. and Walha, K. (2013) Defluoridation of Water by Nanofiltration. Journal of Fluorine Chemistry, 150, 92-97. https://doi.org/10.1016/j.jfluchem.2013.01.021

[18] Guilleux, C., Kochoni, É., Campbell, P.G., Blais, J.F. and Fortin, C. (2015) Géochimie et écotoxicologie des fluorures dans les écosystèmes terrestres et aquatiques et méthodes de traitement: Revue de la littérature scientifique. Centre Eau Terre Environnement, Québec. 
[19] Vassilev, S.V., Eskenazy, G.M. and Vassileva, C.G. (2000) Contents, Modes of Occurrence and Origin of Chlorine and Bromine in Coal. Fuel, 79, 903-921. https://doi.org/10.1016/S0016-2361(99)00236-7

[20] Berland, J.M. and Juery, C. (2002) Les procédés membranaires pour le traitement de l'eau. Document Technique FNDAE, $71 \mathrm{p}$.

[21] Bi, S., Liu, F., Chen, F. and Gan, N. (2000) Speciation of Aluminum Equilibria with Kaolinite in Acidic Natural Water. Journal of Environmental Science \& Health, Part $A$, 35, 1849-1857. https://doi.org/10.1080/10934520009377080

[22] Sébastien, B. (2005) Les techniques de traitement des eaux chargees en arsenic, fluor et plomb. Ministère del'Agriculture et de la Pêche, Paris.

[23] Kurniawan, T.A., Chan, G.Y., Lo, W.H. and Babel, S. (2006) Physico-Chemical Treatment Techniques for Wastewater Laden with Heavy Metals. Chemical Engineering Journal, 118, 83-98. https://doi.org/10.1016/j.cej.2006.01.015

[24] Fu, F. and Wang, Q. (2011) Removal of Heavy Metal Ions from Wastewaters: A Review. Journal of Environmental Management, 92, 407-418.

https://doi.org/10.1016/j.jenvman.2010.11.011

[25] Kut, K.M.K., Sarswat, A., Srivastava, A., Pittman, C.U. and Mohan, D. (2016) A Review of Fluoride in African Groundwater and Local Remediation Methods. Groundwater for Sustainable Development, 2-3, 190-212. https://doi.org/10.1016/j.gsd.2016.09.001

[26] Groupement SGI /Setico (2013) Rapport Technique Sur L'étude Préliminaire de La Station de Fatick. Sacré Coeur III, Dakar.

[27] Mazet, P. (2002) Les Eaux Souterraines Riches En Fluor Dans Le Monde. Rapport de stage. Université des Sciences et Technologies, Montpellier.

[28] Dach, H. (2008) Comparaison Des Opérations de Nanofiltration et D’osmose Inverse Pour Le Dessallement Sélectif Des Eaux Saumatres: De L'echelle Du Laboratoire Au Pilote Industriel. Université d'Angers, Angers.

[29] Aslam, M., Charfi, A., Lesage, G., Heran, M. and Kim, J. (2017) Membrane Bioreactors for Wastewater Treatment: A Review of Mechanical Cleaning by Scouring Agents to Control Membrane Fouling. Chemical Engineering Journal, 307, 897-913. http://dx.doi.org/10.1016/j.cej.2016.08.144

[30] Pontie, M., Buisson, H., Diawara, C.K. and Essis-Tome, H. (2003) Studies of Halide Ions Mass Transfer in Nanofiltration-Application to Selective Defluorination of Brackish Drinking Water. Desalination, 157, 127-134.

https://doi.org/10.1016/S0011-9164(03)00391-6

[31] Diawara, C.K., Lô, S.M., Rumeau, M., Pontie, M. and Sarr, O. (2003) A Phenomenological Mass Transfer Approach in Nanofiltration of Halide Ions for a Selective Defluorination of Brackish Drinking Water. Journal of Membrane Science, 219, 103-112. https://doi.org/10.1016/S0376-7388(03)00189-3

[32] Yang, J., Monnot, M., Ercolei, L. and Moulin, P. (2020) Membrane-Based Processes Used in Municipal Wastewater Treatment for Water Reuse: State-of-the-Art and Performance Analysis. Membranes, 10, Article No. 131.

https://doi.org/10.3390/membranes10060131

[33] Li, D. and Wang, H. (2010) Recent Developments in Reverse Osmosis Desalination Membranes. Journal of Materials Chemistry, 20, 4551-4566. https://doi.org/10.1039/b924553g

[34] Sun, M., Wang, X., Winter, L. R., Zhao, Y., Ma, W., Hedtke, T. and Elimelech, M. (2021) Electrified Membranes for Water Treatment Applications. ACS ES\&T Engi- 
neering, 1, 725-752. https://doi.org/10.1021/acsestengg.1c00015

[35] Mohapatra, M., Anand, S., Mishra, B.K., Giles, D.E. and Singh, P. (2009) Review of Fluoride Removal from Drinking Water. Journal of Environmental Management, 91, 67-77. https://doi.org/10.1016/j.jenvman.2009.08.015

[36] Walha, K., Amar, R.B., Quemeneur, F. and Jaouen, P. (2007) Demineralisation des eaux saumatres du sud tunisien par electrodialyse ou par osmose inverse. Journal Societe Chimique De Tunisie, 9, 133-142.

[37] Figoli, A., Hoinkis, J. and Bundschuh, J. (2016) Membrane Technologies for Water Treatment: Removal of Toxic Trace Elements with Emphasis on Arsenic, Fluoride and Uranium. Johnson Matthey Technology Review, 60, 273-276.

https://doi.org/10.1595/205651316X693283

[38] Malago, J., Makoba, E. and Muzuka, A.N. (2020) Spatial Distribution of Arsenic, Boron, Fluoride, and Lead in Surface and Groundwater in Arumeru District, Northern Tanzania. Fluoride, 53, 356-386.

[39] Sene, H., Ngom, B., Gassama, D. and Tamba, S. (2019) Contribution to the Physico-Chemical Study of Groundwater in Senegal's Groundnut Basin. Journal of Scientific and Engineering Research, 6, 22-29.

[40] Sene, H., Gassama, D., Ngom, B. and Tamba, S. (2019) Underground Risk Study by Principal Component Analysis: Case of Groundwater Application of the Groundnut Basin of Senegal. Journal of Scientific and Engineering Research, 6, 42-46.

[41] Bose, S., Yashoda, R. and Puranik, M.P. (2018) A Review on Defluoridation in India. International Journal of Applied Dental Sciences, 4, 167-171.

[42] Haldar, D., Duarah, P. and Purkait, M.K. (2020) MOFs for the Treatment of Arsenic, Fluoride and Iron Contaminated Drinking Water: A Review. Chemosphere, 251, Article ID: 126388. https://doi.org/10.1016/j.chemosphere.2020.126388 